\title{
Tissue reaction to Endométhasone sealer in root canal fillings short of or beyond the apical foramen
}

\author{
Patrícia SUZUKI ${ }^{1}$, Valdir de SOUZA², Roberto HOLLAND², João Eduardo GOMES-FILHO ${ }^{3}$, Sueli Satomi MURATA ${ }^{4}$, \\ Eloi DEZAN JUNIOR ${ }^{3}$, Thiago Rodrigues dos PASSOS ${ }^{1}$
}

\author{
1- DDS, MSc Postgraduate Program in Endodontics, Dental School, University of Marília (UNIMAR), Marília, SP, Brazil. \\ 2- DDS, MSc, PhD, Titular Professor, Department of Endodontics, Araçatuba Dental School, São Paulo State University, Araçatuba, SP, Brazil; Postgraduate \\ Program in Endodontics, Dental School, University of Marília (UNIMAR), Marília, SP, Brazil. \\ 3- DDS, MSc, PhD, Associate Professor, Department of Endodontics, Araçatuba Dental School, São Paulo State University, Araçatuba, SP, Brazil. \\ 4- DDS, MSc, PhD, Postdoctoral student, Department of Endodontics, Araçatuba Dental School, São Paulo State University, Araçatuba, SP, Brazil.
}

Corresponding address: Dr. João Eduardo Gomes-Filho - Faculdade de Odontologia de Araçatuba - UNESP - Departamento de Odontologia Restauradora - Endodontia - R. José Bonifácio, 1193 - Araçatuba - São Paulo - Brazil - Phone: (0055) 1836363252 - Fax: (0055) 18 36363279 - e-mail: joao@foa.unesp.br

Received: October 1, 2009 - Modification: April 6, 2010 - Accepted: April 8, 2010

\section{ABSTRACT}

\begin{abstract}
bjective: This study evaluated the response of periapical tissues to the endodontic sealer Endométhasone in root canal fillings short of or beyond the apical foramen. Material and Methods: Twenty root canals of premolars and incisors of 2 mongrel dogs were used. After coronal access and pulp extirpation, the canals were instrumented up to a size $55 \mathrm{~K}$-file and the apical cemental barrier was penetrated with a size $15 \mathrm{~K}$-file to obtain a main apical foramen, which was widened to a size $25 \mathrm{~K}$-file. The canals were irrigated with saline at each change of file. The root canals were obturated either short of or beyond the apical foramen by the lateral condensation of gutta-percha and Endométhasone, originating 2 experimental groups: G1: Endométhasone/short of the apical foramen; G2: Endométhasone/beyond the apical foramen. The animals were killed by anesthetic overdose 90 days after endodontic treatment. The individual roots were obtained and serial histological sections were prepared for histomorphological analysis (H\&E and Brown \& Brenn techniques) under light microscopy. The following parameters were examined: closure of the apical foramen of the main root canal and apical opening of accessory canals, apical cementum resorption, intensity of the inflammatory infiltrate, presence of giant cells and thickness and organization of the apical periodontal ligament. Each parameter was scored 1 to 4,1 being the best result and 4 the worst. Data were analyzed statistically by the Wilcoxon nonparametric tests $(p=0.05)$. Results: Comparing the 2 groups, the best result $(p<0.05)$ was obtained with root canal filling with Endométhasone short of the apical foramen but a chronic inflammatory infiltrate was present in all specimens. Conclusions: Limiting the filling material to the root canal space apically is important to determine the best treatment outcome when Endométhasone is used as sealer.
\end{abstract}

Key words: Root canal therapy. Biocompatibility test. Endométhasone.

\section{INTRODUCTION}

The apical limit of obturation and the root canal sealer may influence the final outcome of the endodontic treatment. It has been observed that best results are obtained when the filling material does not overextend beyond the apical foramen. Seltzer, et al. ${ }^{22}$ (1963) reported clinical success in $70.6 \%$ of overextended root fillings, $86.8 \%$ in root canals filled to their full length and $87.2 \%$ in fillings slightly short of the apical foramen. Swartz, et al. ${ }^{26}$ (1983) analyzed 1,007 endodontically treated teeth over a 20-year period and found a success rate of $87.75 \%$, but also observed that overfilled specimens had an approximately 4-fold greater failure rate than those in which the filling material was limited to cemental canal apically. Garcia and Loianno $^{8}$ (1990) evaluated endodontically treated teeth 8 years after root canal therapy and found that underfillings ( 1 to $2 \mathrm{~mm}$ short of the apex) did not interfere with the repair of the periapical tissues, while long overfillings ( $>2 \mathrm{~mm}$ beyond the 
apex) delayed or prevented periodontal healing. The findings of these clinical and radiographic studies have been corroborated by the results of some histomorphological investigations ${ }^{10,11,16,20,23}$.

In addition to the apical limit of obturation, histological evidence has demonstrated that the type of root canal sealer also has an important role in the treatment outcome ${ }^{11,12,17,25}$. In cases where overfilled teeth are in connection with anatomically important structures, such as nerves, blood vessels, or sinus space, the consequences can be severe. Filling materials might act as a foreign body causing mechanical or chemical irritations of periradicular tissues, which may lead to treatment failure ${ }^{5,18,21,27}$.

The most frequently used root canal filling material is gutta-percha with a suitable sealer. Their presence in periradicular tissue, as a foreign body, causes connective tissue responses ${ }^{7}$. Sealers, which fragment into fine particles, are readily phagocytosed by macrophages ${ }^{7}$. The nature and the degree of tissue reaction are related to the type and amount of sealer, the location of the extrusion, and the condition of the periodontal tissues. If the sealer is extruded in the mandibular canal space, it can cause problems that vary from mild inflammatory reactions to severe neurotoxic damage 5,18,21,27. Clinical symptoms are disabling sensory disturbances such as pain, paresthesia, and anesthesia ${ }^{5,27}$. On the other hand, if the overfilled material is in the area of soft tissues, the result can be infection or local irritation ${ }^{5,14}$.

Experimental studies have shown that eugenol and paraformaldehyde are the main materials causing neurotoxic reactions ${ }^{2,3,13,15,18,24}$. Brodin, et al. $^{3}$ (1982) reported that Endométhasone can irreversibly inhibit the conduction of the action potential in the rat phrenic nerve. Serper, et al. ${ }^{24}$ (1998) found that the inhibitory effect of Endométhasone on isolated rat sciatic nerves is reversible but is more pronounced than the effect of Sealapex or Calciobiotic root canal sealers and that only $10 \%-20 \%$ recovery is observed within $2 \mathrm{~h}$.

Radastina, et al. ${ }^{19}$ (1989), observed a strong positive connection between inhibition of the synthetic apparatus of fibroblast development under hydrocortisone effect, this way, it is possible to correlate the toxicity of Endométhasone to the presence of hydrocortisone. On the other hand, Orstavick and Mijör ${ }^{15}$ (1988) observed a low toxicity to Endométhasone.

Considering that overfillings are relatively frequent under clinical conditions and that few histomorphological investigations have investigated the reaction of periapical tissues to Endométhasone, this study evaluated the biocompatibility of this sealer in root canal fillings short of or beyond the apical foramen.

\section{MATERIAL AND METHODS}

Twenty root canals of maxillary and mandibular premolars and maxillary incisors from 2 adult mongrel dogs aged approximately 1 year were used in this study. The research protocol was reviewed and approved by the Research Ethics Committee of the University of Marília, Brazil, in compliance with the ethical guidelines for animal experimentation.

The animals were anesthetized with an intramuscular injection of a combination of xylazine (Coopazine ${ }^{\circledR}$; Coopers do Brasil Ltda, São Paulo, SP, Brazil; $0.05 \mathrm{~mL} / \mathrm{kg}$ body weight) and tiletamine hydrochloride:zolazepam hydrochloride (Zoletil ${ }^{\circledR}-50$; Virbac do Brasil, Indústria e Comércio Ltda, São Paulo, SP, Brazil; 0.2 mL/kg body weight).

The same protocol was used for all teeth. After rubber cup/pumice prophylaxis and rubber dam isolation, the tooth crowns were cleaned with a polyvinylpyrrolidone-iodine solution (AsteriodineAster, Sorocaba, SP, Brazil) and the access cavities were prepared with a \#1090 cylindrical diamond bur (KG Sorensen, Barueri, SP, Brazil). The pulp tissue was extirpated with a size $15 \mathrm{~K}$-file (Maillefer Instruments, Ballaigues, Switzerland), the working length was determined radiographically and the root canals were instrumented up to a size $55 \mathrm{~K}$-file using the crown-down technique until reaching the apical cemental barrier, which was penetrated with a size $15 \mathrm{~K}$-file (Maillefer Instruments). The cemental canal was enlarged up to a size 25 $\mathrm{K}$-file. Throughout the preparation, the root canals were irrigated with saline at each change of file. The instrumented root canals were dried with sterile paper points and immediately obturated by lateral condensation of gutta-percha cones and Endométhasone (Septodont, Saint-Maur-desFossés, France).

The root canals were randomly assigned to 2 groups of 10 specimens each, according to the sealer and the apical limit of obturation: G1: Endométhasone /short of the apical foramen; G2: Endométhasone /beyond the apical foramen. For the teeth in which the fillings ended short of the apical foramen, the sealer was taken to the canal with the main gutta-percha cone, while in those filled beyond the apex the sealer was taken to the canal with a lentulo spiral (Maillefer Instruments) and then the main gutta-percha cone was inserted. Root canal filling was completed with the insertion of accessory gutta-percha points and active lateral condensation with finger spreaders (Maillefer Instruments). Buccolingual radiographs were taken to evaluate the quality of root filling regarding homogeneity and apical extension. Excess material was removed with a heated plugger at the coronal level and the remaining filling material was vertically condensed to obtain well-compacted fillings. The 
pulp chamber was cleaned and the access cavities were sealed with glass ionomer cement (Fuji II LC; GC Corporation, Tokyo, Japan) and silver amalgam (SS White Artigos Dentários Ltda., Rio de Janeiro, RJ, Brazil).

The animals were killed by anesthetic overdose 90 days after treatment. The maxillas and mandibles containing the root-filled teeth were removed, fixed in buffered neutral $10 \%$ formalin, decalcified in $17 \%$ EDTA solution and the individual roots with surrounding tissues were embedded in paraffin. The blocks were cut serially and 6 - $\mu \mathrm{m}$-thick longitudinal sections were obtained, stained with hematoxylin and eosin (H\&E) and Brown and Brenn techniques, and examined under light microscopy by a skilled examiner blinded to the groups. The following histomorphological parameters were examined: closure of the apical foramen of the main root canal and apical opening of accessory canals, apical cementum resorption, intensity of the inflammatory infiltrate, presence of giant cells and thickness and organization of the apical periodontal ligament and (Table 1). Each parameter was scored 1 to 4, 1 being the best result and 4 the worst, according previous established criteria $^{10}$. The obtained data were statistically analyzed by Wilcoxon nonparametric
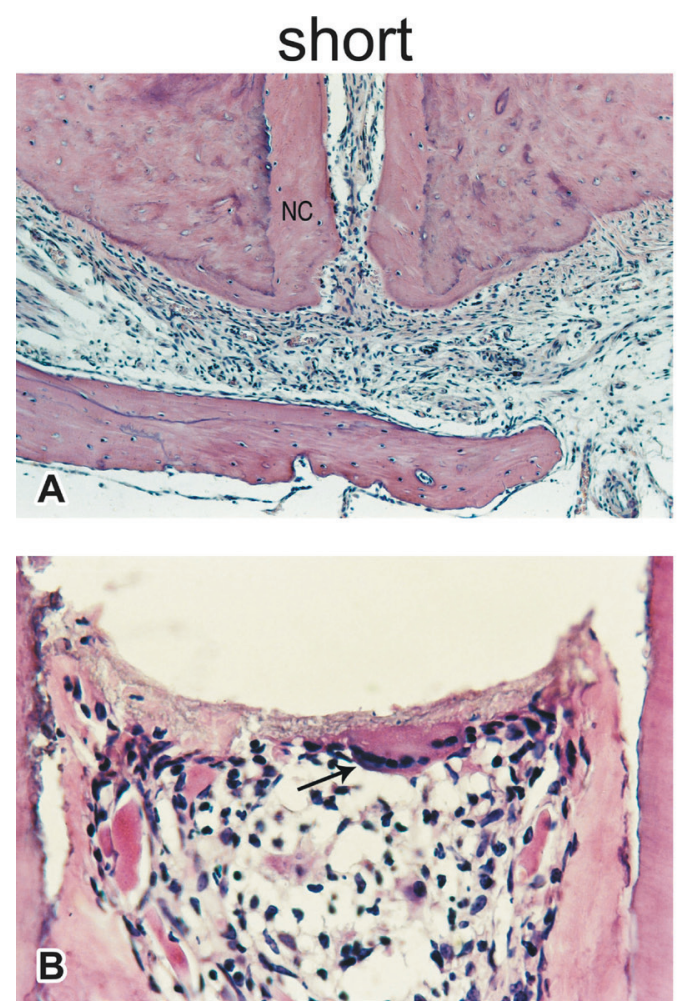

test at $5 \%$ significance level.

\section{RESULTS}

Group 1: (Endométhasone/short of the apical foramen; $n=10)$. The apical foramen of the main canal was patent in 1 specimen. Partial closure of the apical foramen of the main canal was observed in 1 specimen and in the other 8 specimens, deposition of newly formed cementum occurred only on the lateral walls of the cemental canal. Closure of the apical opening of most accessory canals in the apical delta occurred in 8 specimens and in 2 specimens few canals were sealed. The deposition of newly formed cementum repaired all areas of cemental resorption in all specimens. Bacteria and acute inflammatory infiltrate were not observed, but a chronic inflammatory infiltrate was present in all specimens, being severe in 2 specimens, moderate in 1 and mild in 7 specimens (Figure $1 \mathrm{~A}$ ). Discrete presence of giant cells was observed in 2 specimens (Figure 1B). The apical PDL thickness was $395 \mu \mathrm{m}$ on average. The PDL was totally organized in 5 specimens and well-organized in 3/4 of the apical portion in the other 5 specimens.

Group 2 (Endométhasone/beyond the apical

\section{beyond}
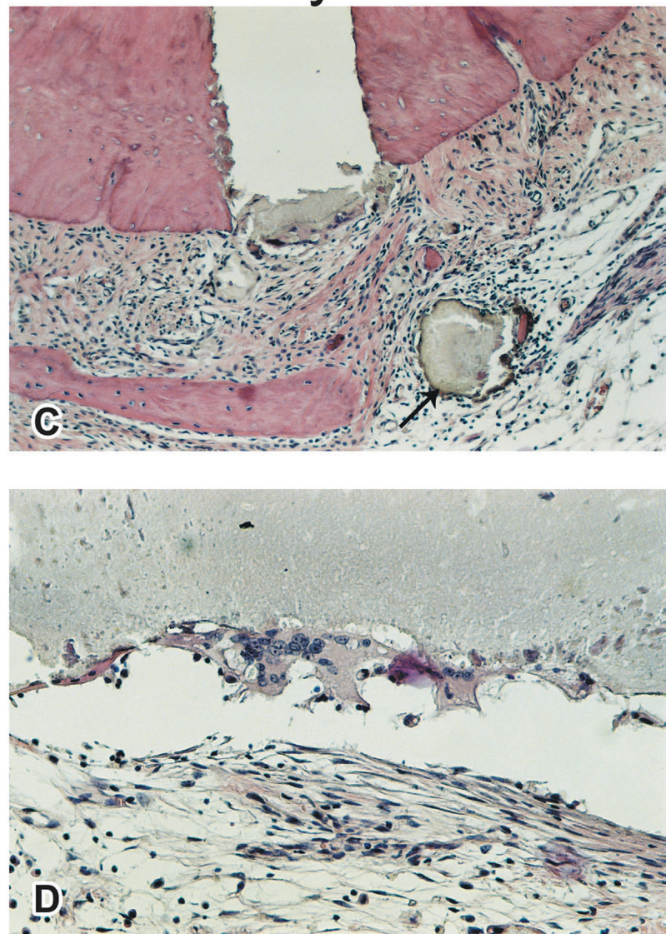

Figure 1- (A) Endométhasone/short of the apical foramen. Deposition of newly formed cementum on the main root canal walls (NC) and presence of mild chronic inflammatory infiltrate $(\mathrm{H} \& \mathrm{E}$, original magnification $\times 100)$. (B) Endométhasone/ short of the apical foramen. Ingrowth of connective tissue into the main root canal with mild chronic inflammatory infiltrate and giant cells close to the filling material (arrow) (H\&E, original magnification $\times 400)$. (C) Endométhasone/beyond the apical foramen. Absence of newly formed cementum close to the main root canal, moderate chronic inflammatory infiltrate and a large sealer fragment in the PDL (arrow) (H\&E, original magnification $\times 100)$. (D) Endométhasone/beyond the apical foramen. Presence of several giant cells in contact with the sealer extruded to the periapical region (H\&E, original magnification $\times 200)$. 
Table 1- Distribution of specimens according to the histomorphological parameters and scores

\begin{tabular}{|c|c|c|c|c|c|}
\hline \multirow[t]{3}{*}{ Histomorphological parameters } & \multirow[t]{3}{*}{ Scores } & \multicolumn{4}{|c|}{ Groups } \\
\hline & & \multicolumn{4}{|c|}{ Endométhasone(n=20) } \\
\hline & & \multicolumn{2}{|c|}{$\begin{array}{l}\text { G1 }(n=10) \\
\text { short }\end{array}$} & \multicolumn{2}{|c|}{$\begin{array}{c}\mathrm{G} 2(\mathrm{n}=10) \\
\text { beyond }\end{array}$} \\
\hline \multirow{4}{*}{$\begin{array}{l}\text { Closure of the apical foramen of the main } \\
\text { root canal }\end{array}$} & $1=$ complete closure & -- & & -- & \\
\hline & $2=$ partial closure & 1 & & -- & \\
\hline & $3=$ deposition on lateral walls & 8 & a & --- & $\mathrm{b}$ \\
\hline & 4=no closure & 1 & & 10 & \\
\hline \multirow{4}{*}{$\begin{array}{l}\text { Closure of the apical opening of the } \\
\text { accessory canals }\end{array}$} & $1=$ all accessory canals & -- & & -- & \\
\hline & $2=$ most accessory canals & 8 & & 3 & \\
\hline & $3=$ few accessory canals & 2 & a & 7 & a \\
\hline & 4=no accessory canals & -- & & -- & \\
\hline \multirow[t]{4}{*}{ Apical cementum resorptions } & $1=$ absent or totally repaired & 10 & & 5 & \\
\hline & $2=$ partially repaired & -- & & -- & \\
\hline & $3=$ non-repaired & -- & a & 5 & $\mathrm{~b}$ \\
\hline & 4=active resorption areas & -- & & -- & \\
\hline \multirow[t]{4}{*}{ Intensity of the inflammatory infiltrate ${ }^{* *}$} & $1=a b s e n t$ & -- & & -- & \\
\hline & $2=$ mild $:<10$ cells & 7 & & 1 & \\
\hline & $3=$ moderate: 11 to 25 cells & 1 & a & -- & $\mathrm{b}$ \\
\hline & 4=severe: $>25$ cells & 2 & & 9 & \\
\hline \multirow[t]{4}{*}{ Presence of giant cells } & $1=a b s e n t$ & 8 & & 2 & \\
\hline & $2=$ discrete: $<3$ cells & 2 & & 6 & \\
\hline & $3=$ moderate: 4 to 6 cells & -- & a & 2 & $\mathrm{~b}$ \\
\hline & $4=$ Intense: $>6$ cells & -- & & -- & \\
\hline \multirow[t]{4}{*}{ Apical PDL thickness ${ }^{* * *}$} & $1 \leq 200 \mu \mathrm{m}$ & 2 & & 1 & \\
\hline & $2=201$ to $300 \mu \mathrm{m}$ & 3 & & 1 & \\
\hline & $3=301$ to $400 \mu \mathrm{m}$ & 1 & a & -- & a \\
\hline & $4>400 \mu \mathrm{m}$ & 4 & & 8 & \\
\hline \multirow[t]{4}{*}{ Apical PDL organization*** } & $\begin{array}{l}1=\text { well-organized PDL in all } 4 \text { parts } \\
\text { of the apical third }\end{array}$ & 5 & & 1 & \\
\hline & 2=well-organized PDL in 3 parts & 5 & a & 7 & a \\
\hline & $3=$ well-organized PDL in 1 or 2 parts & -- & & 2 & \\
\hline & 4=totally disorganized apical PDL & -- & & -- & \\
\hline Group X group comparison & & a & & $b$ & \\
\hline
\end{tabular}

*Different letters indicate statistically significant difference at $5 \%$ (Wilcoxon test). **Inflammatory infiltrate were evaluated in different areas (x400 magnification). ${ }^{* * *}$ The apical root third was divided into 4 parts of similar dimensions. PDL=periodontal ligament

foramen; $n=10)$. The apical foramen of the main canal was patent in all specimens (Fig. 1C). In 3 specimens, the apical opening of most accessory canals in the apical delta were sealed by newly formed cementum, while in the other 7 specimens only few accessory canals presented apical seal. The deposition of newly formed cementum repaired completely the areas of cemental resorption in 5 specimens, while in the other 5 specimens these areas were not repaired. Bacteria and acute inflammatory infiltrate were not observed in any specimen. However, mild and severe lymphocytehistiocyte-plasmocyte infiltrate was found in 1 and 9 specimens, respectively (Figure 1C). Giant 
cells were absent in 2 specimens, but moderate and discrete presence was observed in 2 and 6 specimens, respectively (Figure 1D). The apical PDL thickness was $550 \mu \mathrm{m}$ on average. The PDL was totally organized in 1 specimen and was well organized in 3/4 of the apical portion in 7 specimens and in $1 / 2$ of the apical portion in the other 2 specimens.

Distribution of specimens according to the histomorphological parameters and scores is presented in Table 1.

\section{Statistical Analysis}

When the apical limit of obturation was analyzed, the fillings ending short of the apical foramen presented significantly better periapical response than those extended beyond the apex $(p=0.05)$ (Table 1).

\section{DISCUSSION}

In this study, none of the obturation limits proposed for the endodontic treatment using Endométhasone was completely successful in maintaining the normality of the periapical tissues within a relatively short evaluation period (90 days). A chronic inflammatory infiltrate was present regardless of the apical limit of obturation, being more severe in the group in which the filling material was overextended. The worst periapical response was obtained with the overfillings, which is consistent with the findings of previous histomorphological investigations ${ }^{10,11,16,20,23}$. It is assumed that the inflammatory response developed in cases of overfilling may be related to the pressure and trauma exerted by the filling material extruded to the periapical region ${ }^{6,9}$.

In the root canals obturated beyond the apex, an interesting finding was the absence of ingrowth of connective tissue into the canal in all specimens overfilled with Endométhasone. A previous histopathological and $x$-ray microanalysis of the subcutaneous tissue response to endodontic sealers found that zinc oxide-eugenol-based materials appeared more resistant to fragment into smallsized particles for macrophage phagocytosis ${ }^{15}$ as observed with other sealers such as EndoREZ that showed the presence of macrophages and foreignbody giant cells with engulfed sealer particles in their cytoplasm when implanted in subcutaneous tissue $^{28}$. Therefore, proper attention should be given to the apical limit of root canal obturation during the endodontic treatment because sealer extrusion to the periapical region may be responsible for the increase or persistency of posttreatment residual chronic inflammation, which is rarely diagnosed radiographically ${ }^{4,15}$.
The findings of this study regarding the biocompatibility of Endométhasone are in agreement with those of previous investigations that reported the presence of inflammatory infiltrate in the periapical region of monkey's teeth 180 days after endodontic treatment ${ }^{1,16}$. It has been considered that the absence of periapical inflammation and the closure of the main apical foramen and accessory apical openings by deposition of newly formed cementum represent the ideal repair after root canal obturation ${ }^{10,11}$. In the present study, the absence of complete closure of the main foramen and the presence of chronic inflammatory infiltrate in all specimens, with higher intensity and extension in the overextended group, demonstrated that Endométhasone did not provide the ideal endodontic healing. However, the presence of fibrous connective tissue partially surrounding large fragments of the sealer, as observed in some specimens, suggests that complete encapsulation of the large particles of the material may occur within longer periods, reducing the periapical inflammatory infiltrate.

\section{CONCLUSIONS}

Based on the methodology employed and the results of the present study, it may be concluded that limiting the filling material to the root canal space apically is important to determine the best treatment outcome when Endométhasone was used is sealer.

\section{REFERENCES}

1- Bouillaguet S, Wataha JC, Lockwood PE, Galgano C, Golay A, Krejci I. Cytotoxicity and sealing properties of four classes of endodontic sealers evaluated by succinic dehydrogenase activity and confocal laser scanning microscopy. Eur J Oral Sci. 2004;112:182-7.

2- Brodin P. Neurotoxic and analgesic effects of root canal cements and pulp-protecting dental materials. Endod Dent Traumatol. 1988;4:1-11.

3- Brodin P, Røed A, Aars H, Orstravik D. Neurotoxic effects of root filling materials on rat phrenic nerve in vitro. J Dent Res. 1982;61:1020-3.

4- Brynolf I. A histological and roentgenological study of the periapical region of human upper incisors. Odontol Revy. 1967;18(Suppl 11):1-176.

5- Ektefaie MR, David HT, Poh CF. Surgical resolution of chronic tissue irritation caused by extruded endodontic filling material. J Can Dent Assoc. 2005;71:487-90.

6- Erausquin J, Muruzábal M, Devoto FC, Rikles A. Necrosis of the periodontal ligament in root canal overfillings. J Dent Res. 1966;45:1084-92.

7- Fardal O, Johannessen AC, Morken T. Gingivo-mucosal and cutaneous reactions to amalgam fillings. J Clin Periodontol. 2005;32:430-3.

8- Garcia JR, Loianno F. Accidental overfilling with medicated cement. Rev Soc Odontol La Plata. 1990;3:7-10.

9- Holland R, Maisto OA, Souza V, Maresca BM, Nery MJ. Action and speed of reabsorption of distinct root canal filling materials in the periapical connective tissue. Rev Asoc Odontol Argent. 1981:69:7-17. 
10- Holland R, Mazuqueli L, Souza V, Murata SS, Dezan Júnior E, Suzuki P. Influence of the type of vehicle and limit of obturation on apical and periapical tissue response in dogs' teeth after root canal filling with mineral trioxide aggregate. J Endod. 2007:33:693-7. 11- Holland R, Souza V. Ability of a new calcium hydroxide root canal filling material to induce hard tissue formation. J Endod. $1985 ; 11: 535-43$

12- Leonardo MR, Silva LA, Utrilla LS, Assed S, Ether SS. Calcium hydroxide root canal sealers - histopathologic evaluation of apical and periapical repair after endodontic treatment. J Endod. 1997;23:428-32.

13- Morse DR. Infection-related mental and inferior alveolar nerve paresthesia: literature review and presentation of two cases. J Endod. 1997;23:457-60.

14- Muruzábal M, Erasquin J. Response of periapical tissues in the rat molar to root fillings with Diaket and $\mathrm{AH}-26$. Oral Surg Med Oral Pathol. 1966;21:786-804

15- Orstavik D, Mjör IA. Histopatoloy and x-ray microanalysis of the subcutaneous tissue response to endodontic sealers. J Endod. $1988 ; 14: 13-23$.

16- Orstavik D, Mjör IA. Usage test of four endodontic sealers in Macaca fascicularis monkeys. Oral Surg Oral Med Oral Pathol. 1992;73:337-44.

17- Pitt Ford TR. Tissue reactions to two root canal sealers containing formaldehyde. Oral Surg Oral Med Oral Pathol. 1985;60:661-5.

18- Pogrel MA. Damage to the inferior alveolar nerve as the result of root canal therapy. J Am Dent Assoc. 2007;138:65-9.

19- Radostina AL, Zumangi N, Malomu U-UF. Changes in the ultrastructure and fibrogenic activity of rat dermal fibroblasts as affected by various doses of hidrocortisone. Arkh Anat Gistol Embriol. 1989;96:52-8
20- Ricucci D, Langeland K. Apical limit of root canal instrumentation and obturation, part 2. A histological study. Int Endod J. 1998;31:394-409.

21- Scolozzi P, Lombardi T, Jaques B. Successful inferior alveolar nerve decompression for dysesthesia following endodontic treatment: report of 4 cases treated by mandibular sagittal osteotomy. Oral Surg Oral Med Oral Pathol Oral Radiol Endod. 2004;97:625-31.

22- Seltzer S, Bender IB, Turkenkopf S. Factors affecting successful repair after root canal therapy. J Am Dent Assoc. 1963:67:651-62. 23- Seltzer S, Soltanoff W, Smith J. Biologic aspects of endodontics. V. Periapical tissue reactions to root canal instrumentation beyond the apex and root canal fillings short of and beyond the apex. Oral Surg Oral Med Oral Pathol. 1973;36:725-37.

24- Serper A, Uçer O, Onur R, Etikan I. Comparative neurototxic effects of root canal materials on rat sciatic nerve. J Endod. $1998 ; 24: 592-4$.

25- Souza RS, Gandini LG Jr, Souza V, Holland R, Dezan E Jr. Influence of orthodontic dental movement on the healing process of teeth with periapical lesions. J Endod. 2006;32:115-9.

26- Swartz DB, Skidmore AE, Griffin JA Jr. Twenty years of endodontic success and failure. J Endod. 1983:9:198-202.

27- Yamaguchi K, Matsunaga T, Hayashi Y. Gross extrusion of endodontic obturation materials into the maxillary sinus: a case report. Oral Surg Oral Med Oral Pathol Oral Radiol Endod 2007;104:131-4.

28- Zmener O. Tissue response to a new methacrylate-based root canal sealer: preliminary observations in the subcutaneous connective tissue of rats. J Endod. 2004;30:348-51. 